\title{
Article
}

\section{Food safety and evaluation of intention to practice safe eating out measures during COVID-19: Cross sectional study in Indonesia and Malaysia}

Soon, Jan Mei, Wahab, Ikarastika Rahayu Abdul, Hamdan, Ruhil Hayati and Jamaludin, Mohd Hafiz

Available at http://clok.uclan.ac.uk/36793/

Soon, Jan Mei ORCID: 0000-0003-0488-1434, Wahab, Ikarastika Rahayu Abdul, Hamdan, Ruhil Hayati and Jamaludin, Mohd Hafiz (2021) Food safety and evaluation of intention to practice safe eating out measures during COVID-19: Cross sectional study in Indonesia and Malaysia. Food Control . ISSN 09567135

It is advisable to refer to the publisher's version if you intend to cite from the work. http://dx.doi.org/10.1016/j.foodcont.2021.107920

For more information about UCLan's research in this area go to http://www.uclan.ac.uk/researchgroups/ and search for <name of research Group>.

For information about Research generally at UCLan please go to http://www.uclan.ac.uk/research/

All outputs in CLoK are protected by Intellectual Property Rights law, including Copyright law. Copyright, IPR and Moral Rights for the works on this site are retained by the individual authors and/or other copyright owners. Terms and conditions for use of this material are defined in the policies page. 


\title{
Structural equation modelling of food safety knowledge, attitude and practices among consumers in Malaysia
}

\author{
Jan Mei Soon ${ }^{1}$, Ikarastika Rahayu Abdul Wahab², Ruhil Hayati Hamdan³, Mohd Hafiz Jamaludin² \\ ${ }^{1}$ Faculty of Health and Wellbeing, University of Central Lancashire, Preston, PR1 2HE UK \\ ${ }^{2}$ Faculty of Agro-Based Industry, Universiti Malaysia Kelantan, 17600 Jeli, Kelantan, Malaysia \\ ${ }^{3}$ Faculty of Veterinary Medicine, Universiti Malaysia Kelantan, 16100 Kota Bharu, Kelantan, Malaysia
}

\section{Abstract}

Factors contributing to foodborne illnesses in Malaysia were identified as insanitary food handling procedures and lack of hygiene in food preparation area. Food safety at home is a critical point as consumers represent the final step in food preparation and prevention of foodborne diseases. This study aims to investigate the food safety knowledge, attitude and self-reported practices among consumers in Malaysia. An online survey was conducted, and data were analysed using descriptive statistics and exploratory factor analysis. A model linking food safety knowledge and attitude and their direct effects on practices were confirmed using structural equation modelling (SEM). The proposed model fulfilled the goodness of fit indices and is deemed acceptable. Respondents demonstrate good level of food safety knowledge and positive attitudes and self-reported practices. Food safety knowledge has a negative and insignificant relationship with food safety practices ( $\beta 1=-$ $0.284, p>0.05)$ while attitude significantly affects food safety practices $(\beta 1=0.534, p<0.05)$. The findings clearly indicate that food safety knowledge does not directly affect food safety practices This is also the first study to provide new empirical findings on thermometer usage among consumers in Malaysia. This study establishes an important point of reference where consumers use visual appearances to determine if food is thoroughly cooked and practice washing raw chicken prior to cooking. Food safety practices at home play a critical role in protecting consumers in reducing risks of foodborne illnesses.

Keywords: cross contamination; food safety; hygiene; thermometer

\section{Introduction}

The World Health Organization estimated that foodborne diseases caused 600 million cases and 420,000 deaths annually of which $30 \%$ of the fatalities occur among children under 5 years of age [1]. The main contributing factor to foodborne diseases in Malaysia was identified as insanitary food handling procedures and lack of cleanliness in premises which accounted for more than $50 \%$ of the poisoning incidents [2]. Most of the reported outbreaks were recorded at educational institutions and schools. This has led to an increase of food safety studies on knowledge, attitude and practices

\footnotetext{
${ }^{1}$ Corresponding author: imsoon@uclan.ac.uk
} 
among commercial food handlers in Malaysia [3-7]. These studies consistently revealed that food handlers were unaware of different foodborne pathogens and had poor to average knowledge of hygienic practices in food handling. Abdul-Mutalib et al. [8] revealed that although the food handlers in their study exhibited excellent level of food safety knowledge and attitude, they could further improve on hygiene practices such as cleaning the food preparation and working area and to avoid wearing jewelleries whilst working. Although numerous studies had been conducted among food handlers at food service operations, food safety at home is another critical point as consumers represent the final step in food preparation and prevention of foodborne diseases. More than $35 \%$ of foodborne diseases occurred at home [9]. This represents the tip of the iceberg as the number of reported cases are underestimated due to the lack of outbreak reports in home settings $[10,11]$. Consumers who misinterpret foodborne disease symptoms or treat food poisoning symptoms as transient inconveniences represent the reasons why consumers do not often seek medical treatment $[9,11,12]$.

The evaluation of food safety among Malaysian consumers had been conducted although the studies were mostly conducted in East Malaysia [12-14]. Ruby et al. [14] discovered that all the Theory of Planned Behaviour antecedents i.e. food safety knowledge, subjective norm and perceived behavioural control showed significant effects on the intention of safe food handling. One of the key predictors of intention to safe food handling were subjective norm, demonstrating that encouragement from family members could improve food safety practices at home. Lim et al. [12] evaluated the consumers' knowledge of hygienic practices and revealed that consumers demonstrated poor attitude in the use of cutting boards and used the floor as cutting board instead. Ruby et al. [13] further assessed consumers' food safety knowledge of personal hygiene, foodborne disease symptoms, high risk foods, cross contamination and temperature control. The overall food safety knowledge of adult consumers was considered good but was seriously lacking in knowledge of temperature control. Similarly, a survey on microwave oven safety revealed low level of microwave oven knowledge and safety practices [15]. More than $70 \%$ of the respondents did not reheat food periodically nor stir their food midway of the reheating process. This could potentially lead to nonuniform heating leading to presence of cold spots which will allow bacteria (if present) to survive and grow when conditions are optimal. Knowledge of temperature control remain poor among consumers and food handlers. This is supported by an intervention study conducted by Nik Husain, Wan Muda, Norr Jamil, Nik Hanafi, \& Abdul Rahman [16] where food safety training failed to increase knowledge of temperature control such as awareness of the temperature danger zone and the correct temperatures for food storage and heating.

Temperature control and thermometer usage remain a challenge in Malaysia, not only among commercial food handlers but even more so among food handlers at home. The hot and humid climate of this country contributes to the optimal growth of most mesophilic foodborne pathogens 
[17]. To what extent do consumers use thermometers at home? What are the reasons for not using a thermometer? There is also a lack of food safety studies among consumers in Peninsular Malaysia. This study investigates the food safety knowledge, attitude towards food safety and food safety practices among general consumers. Food safety knowledge refers to the understanding of or information about food acquired through experience or education while attitude is a feeling or opinion about food safety and practice refers to the action or application of food safety. Structural equation modelling (SEM) had been used in a number of food safety studies [12, 18-21]. In this study, the author postulates the following hypotheses based on $12,18,20$. This study proposed the following hypotheses:

H1: Food safety knowledge does not directly affect food safety practices

H2: Attitude towards food safety directly affects food safety practices

H3: Food safety knowledge and attitude are correlated

This study utilises SEM as a confirmatory technique to determine the proposed model validity and to examine the relationship between food safety knowledge, attitude and practices among consumers in Malaysia.

\section{Methodology}

\section{Questionnaire development}

The questionnaire was constructed based on 12, 18, 22-23 and was divided into 5 sections: (i) demographics; (ii) thermometer usage; (iii) knowledge; (iv) attitudes and (v) practices. The surveys conducted in previous studies were based on recommended food safety handling practices and fulfilled the WHO Five Keys to Safer Food practices [23] i.e. keep clean; separate raw and cooked; cook thoroughly; keep food at safe temperatures; and use safe water and raw materials. In the food safety knowledge section, participants were provided with optional answers i.e. 'yes', 'no' and 'uncertain' to prevent participants from selecting the correct answer by chance. The food safety attitude and practices questions allow participants to rate on a 5-point Likert scale of strongly disagree/never to strongly agree/always. The questionnaire was provided in both English and Malay languages. The questions were translated into Malay and back translated into English to ensure accuracy. A pilot study was conducted among 15 participants at a local university to evaluate the language, clarity and suitability of wordings. The pilot data were not included in the final analysis. A copy of the questionnaire in both Malay and English is provided in Supporting Information (S1 Questionnaire).

\section{Data collection}

Ethical approval was obtained and granted by University of Central Lancashire HEALTH Ethics committee (0009). The questionnaire was uploaded onto Online Survey (previously Bristol Online 
Survey) and sends an online survey announcement to its sample pool and recruit respondents over the age of 18 for this study. The inclusion criteria for the participants are that they should be adult Malaysia residents and are currently residing in Malaysia. Participant consent was obtained before the start of the survey and all participants could withdraw from the survey by simply exiting or closing the browser page. Survey is a useful tool to obtain a high volume of information from a large number of people in a short period of time [24]. The online survey was conducted between June - September 2019. A reminder was sent to all potential respondents in August 2019 to boost the number of responses. All returned responses were checked and verified by the authors to ensure completion. $A$ total of 793 questionnaires were returned of which 787 surveys were valid. Fully completed surveys were deemed as valid responses.

\section{Statistical analysis}

Descriptive and Exploratory Factor Analysis (EFA) was conducted using Statistical Package for Social Science (SPSS) 26.0 software. EFA was performed to extract valid items for knowledge, attitude and practices. This is based on factor loadings of the scale items greater than 0.40 (Baser et al., 2017). Confirmatory Factor Analysis (CFA) was performed using Analysis of Moment Structures (AMOS) and confidence level was set at $95 \%$.

\section{Results}

Table 1 shows the demographic characteristics of the participants. Up to $2 / 3$ of the respondents are female and $87.0 \%$ are below the age of 36 and more than $90 \%$ are currently studying at institutions of higher education or had received tertiary education. Up to $75.7 \%$ of the respondents reported having experienced symptoms of food poisoning with diarrhoea $(71.2 \%)$ and vomiting $(56.4 \%)$ being the most common symptoms. Although $85.1 \%$ of respondents prepared meals at home, only $15.1 \%$ reported using a thermometer. Amongst those who reported using a thermometer, $91.6 \%$ of them uses the thermometer correctly. The main reasons for not using a thermometer was that the respondents knew the food is cooked by checking its visual appearance $(53.3 \%)$, troublesome to use it (15.3\%) and do not know how to use it (10.9\%).

Table 1 Demographic characteristics of participants $(n=787)$

\begin{tabular}{|l|l|l|}
\hline Variable & Items & Frequency (\%) \\
\hline Gender & Male & $222(28.2)$ \\
\hline & Female & $565(71.8)$ \\
\hline Age & & \\
\hline & $18-25$ & $294(37.4)$ \\
\hline & $26-35$ & $390(49.6)$ \\
\hline & $36-45$ & $69(8.8)$ \\
\hline & $46-55$ & $29(3.7)$ \\
\hline & $\geq 56$ & $5(0.6)$ \\
\hline Education & & \\
\hline & Primary & $4(0.5)$ \\
\hline
\end{tabular}




\begin{tabular}{|c|c|c|}
\hline & Tertiary & $722(91.7)$ \\
\hline \multirow{3}{*}{$\begin{array}{l}\text { Have you experienced food } \\
\text { poisoning before }\end{array}$} & Yes & $596(75.7)$ \\
\hline & No & $127(16.1)$ \\
\hline & Uncertain & $64(8.1)$ \\
\hline \multirow{11}{*}{$\begin{array}{l}\text { What were the symptoms } \\
\text { experienced? Please tick any } \\
\text { that applies: }\end{array}$} & Nausea & 307 \\
\hline & Vomiting & 444 \\
\hline & Diarrhoea & 560 \\
\hline & Stomach cramps & 443 \\
\hline & Fever & 188 \\
\hline & Tired & 354 \\
\hline & Aches & 158 \\
\hline & Chills & 127 \\
\hline & Headaches & 160 \\
\hline & Loss of appetite & 321 \\
\hline & Others & 4 \\
\hline \multirow{3}{*}{$\begin{array}{l}\text { Do you prepare your own or } \\
\text { for family meals? }\end{array}$} & Yes & $307(39.0)$ \\
\hline & No & $117(14.9)$ \\
\hline & Sometimes & $363(46.1)$ \\
\hline \multirow{5}{*}{$\begin{array}{l}\text { If you use a thermometer, } \\
\text { how do you use it to check } \\
\text { the food? }\end{array}$} & Place on top of food & $5(0.6)$ \\
\hline & Place thermometer on side of food & $2(0.3)$ \\
\hline & $\begin{array}{l}\text { Place thermometer in the centre of the thickest } \\
\text { part of the food }\end{array}$ & $109(13.9)$ \\
\hline & Place thermometer on the side of the pot & $3(0.4)$ \\
\hline & I don't use a thermometer & $668(84.9)$ \\
\hline \multirow{6}{*}{$\begin{array}{l}\text { If you do not use a } \\
\text { thermometer, what is the } \\
\text { main reason for not using it? }\end{array}$} & $\begin{array}{l}\text { I know the food is cooked by checking its } \\
\text { visual appearance }\end{array}$ & $356(53.3)$ \\
\hline & Troublesome to use it & $102(15.3)$ \\
\hline & Other people don't use it & $31(4.6)$ \\
\hline & Don't know how to use it & $73(10.9)$ \\
\hline & $\begin{array}{l}\text { There is no need for a thermometer - I've not } \\
\text { had any food poisoning problems }\end{array}$ & $49(7.3)$ \\
\hline & It can be a source of contamination & $57(8.5)$ \\
\hline
\end{tabular}

Table 2 shows the result of food safety knowledge, proportion of correct answers and standard loading of items. All standard loadings were $>0.40$. More than $80 \%$ of the respondents answered half of the questions correctly. In K4 however, only $3.2 \%$ of the respondents knew that raw chicken should not be washed prior to preparation. Tables 3 and 4 present the results of food safety attitude and practices scale. Similarly, all standard loadings were higher than 0.40 . Respondents mostly demonstrated positive attitude and safe food practices. The overall mean score for A2 was $2.92 \pm 1.29$ 
and represented a general disagreement among the respondents in their attitude when sneezing or

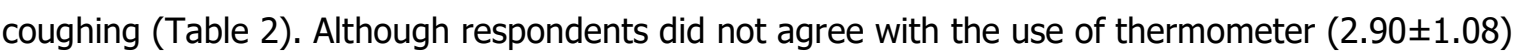
(Table 3), most relied on visual appearance $(4.00 \pm 1.18)$ to determine if the food is thoroughly cooked, e.g. fish should be flaky and opaque, or egg yolk and egg white should be firm (Table 4).

Table 2 Food safety knowledge and frequency of correct answers

\begin{tabular}{|c|c|c|c|}
\hline Item & Description & $\begin{array}{l}\text { Correct answers } \\
\text { Frequency }(\%)\end{array}$ & Standard loadings \\
\hline K1 & $\begin{array}{l}\text { Hands should be washed before meal } \\
\text { preparation to prevent food poisoning }\end{array}$ & $\begin{array}{c}\text { Yes } \\
778(98.9)\end{array}$ & 0.74 \\
\hline K2 & $\begin{array}{l}\text { Diarrhoea can be transmitted by } \\
\text { consuming contaminated food }\end{array}$ & $\begin{array}{c}\text { Yes } \\
748(95.0)\end{array}$ & 0.66 \\
\hline K3 & Pets are allowed into the kitchen area & $\begin{array}{c}\text { No } \\
666(84.6)\end{array}$ & 0.48 \\
\hline K4 & $\begin{array}{l}\text { Raw chicken should be washed before } \\
\text { preparation }\end{array}$ & $\begin{array}{c}\text { No } \\
25(3.2) \\
\end{array}$ & 0.60 \\
\hline K5 & $\begin{array}{l}\text { If cooking meat and poultry, the juices } \\
\text { should be clear and not pink when } \\
\text { cooked }\end{array}$ & $\begin{array}{c}\text { Yes } \\
647(82.2)\end{array}$ & 0.47 \\
\hline K6 & Runny eggs are safe to eat & $\begin{array}{c}\text { No } \\
413(52.5)\end{array}$ & 0.62 \\
\hline K7 & $\begin{array}{l}\text { Separate equipment such as chopping } \\
\text { boards and utensils are used for raw } \\
\text { meat and cooked food }\end{array}$ & $\begin{array}{c}\text { Yes } \\
632(80.3)\end{array}$ & 0.53 \\
\hline K8 & $\begin{array}{l}\text { Raw meat can be stored anywhere in } \\
\text { the refrigerator as long as it's chilled }\end{array}$ & $\begin{array}{c}\text { No } \\
661(84.0) \\
\end{array}$ & 0.55 \\
\hline K9 & $\begin{array}{l}\text { Food preparation utensils can be } \\
\text { washed with pipe water only }\end{array}$ & $\begin{array}{c}\text { No } \\
435(55.3)\end{array}$ & 0.64 \\
\hline K10 & $\begin{array}{l}\text { Frozen food is thawed at room } \\
\text { temperature }\end{array}$ & $\begin{array}{c}\text { No } \\
128(16.3)\end{array}$ & 0.52 \\
\hline K11 & $\begin{array}{l}\text { Cooked food should be served hot } \\
\text { (more than } 60^{\circ} \mathrm{C} \text { ) }\end{array}$ & $\begin{array}{c}\text { Yes } \\
470(59.7)\end{array}$ & 0.54 \\
\hline K12 & $\begin{array}{l}\text { Leftover food can be stored at room } \\
\text { temperature to be eaten at the next } \\
\text { meal }\end{array}$ & $\begin{array}{c}\text { No } \\
565(71.8)\end{array}$ & 0.49 \\
\hline
\end{tabular}

Table 3 Mean scores of items in attitude towards food safety (1: Strongly disagree to 5: Strongly agree)

\begin{tabular}{|c|c|c|c|c|}
\hline Items & Description & Mean & $\begin{array}{l}\text { Standard } \\
\text { deviation }\end{array}$ & $\begin{array}{l}\text { Standard } \\
\text { loadings }\end{array}$ \\
\hline A1 & Washing hands with soap can prevent food poisoning & 3.91 & 1.41 & 0.91 \\
\hline A2 & $\begin{array}{l}\text { When coughing / sneezing, we should cough/sneeze } \\
\text { into our elbow if we do not have a tissue close by }\end{array}$ & 2.92 & 1.29 & 0.53 \\
\hline A3 & $\begin{array}{l}\text { Hand injuries or cuts are covered to prevent cross } \\
\text { contamination of food }\end{array}$ & 3.89 & 1.39 & 0.91 \\
\hline A4 & $\begin{array}{l}\text { Fruits and vegetables (e.g. ulam) are washed before } \\
\text { eating }\end{array}$ & 4.14 & 1.46 & 0.94 \\
\hline A5 & I do not use damaged or cracked eggs & 3.97 & 1.47 & 0.87 \\
\hline A6 & $\begin{array}{l}\text { If I use a thermometer, I will clean it with water and } \\
\text { soap each time after using }\end{array}$ & 3.62 & 1.35 & 0.82 \\
\hline
\end{tabular}




\begin{tabular}{|c|l|c|c|c|}
\hline A7 & $\begin{array}{l}\text { Raw meat is stored at the bottom of the refrigerator } \\
\text { shelf }\end{array}$ & 2.37 & 1.39 & 0.54 \\
\hline A8 & $\begin{array}{l}\text { If there is only one chopping board, it should be } \\
\text { washed after using it to prepare raw meat / poultry / } \\
\text { seafood }\end{array}$ & 3.92 & 1.44 & 0.90 \\
\hline A9 & $\begin{array}{l}\text { It is adequate to use one kitchen towel for all cleaning } \\
\text { and drying purposes }\end{array}$ & 1.89 & 1.10 & 0.79 \\
\hline A10 & $\begin{array}{l}\text { Leftover food is kept at room temperature, so I don't } \\
\text { have to reheat it }\end{array}$ & 1.72 & 0.95 & 0.80 \\
\hline A11 & $\begin{array}{l}\text { Thermometer should be used to check if a food is } \\
\text { thoroughly cooked }\end{array}$ & 2.90 & 1.08 & 0.52 \\
\hline A12 & \begin{tabular}{l} 
Frozen food is kept at room temperature to defrost \\
\hline
\end{tabular} & 3.27 & 1.35 & 0.68 \\
\hline
\end{tabular}

162

163

Table 4 Mean scores of items in food safety practices (1: Never to 5: Always)

\begin{tabular}{|c|c|c|c|c|}
\hline Items & Description & Mean & $\begin{array}{l}\text { Standard } \\
\text { deviation }\end{array}$ & $\begin{array}{l}\text { Standard } \\
\text { loadings }\end{array}$ \\
\hline P1 & $\begin{array}{l}\text { I wash my hands with soap after using the } \\
\text { toilet }\end{array}$ & 4.21 & 1.22 & 0.85 \\
\hline P2 & $\begin{array}{l}\text { I wash my hands if I sneezed or coughed } \\
\text { into my hands while preparing food }\end{array}$ & 4.14 & 1.27 & 0.83 \\
\hline P3 & $\begin{array}{l}\text { If I have a pet (e.g. cat or dog) it's free to } \\
\text { roam in the kitchen area }\end{array}$ & 1.92 & 1.21 & 0.67 \\
\hline P4 & $\begin{array}{l}\text { When purchasing food, I select fresh and } \\
\text { wholesome food }\end{array}$ & 4.28 & 1.15 & 0.89 \\
\hline P5 & $\begin{array}{l}\text { I wash raw meat before cutting or } \\
\text { preparing them }\end{array}$ & 4.29 & 1.25 & 0.82 \\
\hline $\mathrm{P} 6$ & I do not use food beyond its expiry date & 4.10 & 1.33 & 0.77 \\
\hline P7 & $\begin{array}{l}\text { I clean food preparation areas and utensils } \\
\text { after preparing raw meat / poultry / } \\
\text { seafood }\end{array}$ & 4.32 & 1.19 & 0.90 \\
\hline P8 & $\begin{array}{l}\text { I chopped vegetables using a separate or } \\
\text { a clean chopping board }\end{array}$ & 3.86 & 1.34 & 0.72 \\
\hline P9 & $\begin{array}{l}\text { I use the same kitchen towel to wipe } \\
\text { kitchen surfaces and dry my hands }\end{array}$ & 1.93 & 1.26 & 0.69 \\
\hline $\mathrm{P} 10$ & I check if the food is cooked by tasting it & 3.43 & 1.38 & 0.44 \\
\hline P11 & $\begin{array}{l}\text { I check if the food is cooked by visual } \\
\text { appearance (e.g. fish should be opaque } \\
\text { and flaky; egg yolk and white should be } \\
\text { firm) }\end{array}$ & 4.00 & 1.18 & 0.76 \\
\hline P12 & $\begin{array}{l}\text { Leftover food from lunch are kept at room } \\
\text { temperature until the next meal (e.g. } \\
\text { dinner) }\end{array}$ & 2.72 & 2.29 & 0.47 \\
\hline
\end{tabular}

The Kaiser-Meyer-Olkin (KMO) measure of sampling values were $0.69,0.94$ and 0.93 for food safety knowledge, attitude and practices . According to Hair, Black, Babin, Anderson and Tatham [25], the $\mathrm{KMO}$ values should be more than 0.60 , hence the criterion of validity is met. Table 5 shows the various goodness of fit indices in comparison with reported accepted values. Whilst evaluating the goodness of fit indices, it is recommended to use more than one indicator to evaluate model fit [20, 26] . Apart from Normed Fit Index (NFI) which measured slight below 0.90, all fit indices fulfil the accepted values. Both Comparative Fit Index (CFI) and Goodness of Fit Index (GFI) were estimated at 0.937 and 0.906 and indicates good fit. The Root Mean Square Error of Approximation (RMSEA) 
measured below 0.10 and was considered a good fit [27] while Root Mean Square Residual (RMR) was below 0.08 , stipulating an acceptable fit [28]. Thus, the hypothesised model for food safety knowledge, attitude and practices had a good fit and is acceptable. The structural model between the variables of food safety knowledge, attitude and practices is shown in Figure 1.

Table 5 Goodness of fit indices

\begin{tabular}{|l|l|l|}
\hline Fit indices & Model value & Accepted value \\
\hline$\chi^{2} / \mathrm{df}$ & 2.335 & $<3[29]$ \\
\hline Comparative Fit Index (CFI) & 0.937 & $>0.90[28]$ \\
\hline Goodness of Fit Index (GFI) & 0.906 & $>0.90[30]$ \\
\hline Root Mean Square Error of Approximation (RMSEA) & 0.041 & $<0.10[27]$ \\
\hline Normed Fit Index (NFI) & 0.894 & $>0.90[31]$ \\
\hline Root Mean Square Residual (RMR) & 0.054 & $<0.08[28]$ \\
\hline
\end{tabular}

179

180

181

182

183

184

185

186

187

188

189

190

191

192

193

194

195

196

197

198

199

200

201

202

Insert Figure 1 here

The direction and extent of relationships in the food safety knowledge and attitude and their direct effects on practices model is shown in Figure 1 and Table 6. Food safety knowledge has a negative and insignificant relationship ( $\beta 1=-0.284, p>0.05)$ with food safety practices hence rejecting hypothesis 1 . The findings clearly indicate that food safety knowledge does not directly affect food safety practices. Based on the magnitude (i.e. $\beta 1=-0.284, p>0.05$ ) and direction (i.e. negative relationship) of the model, food safety practices will possibly decrease 0.28 unit with each unit increase in knowledge. The second hypothesis $(\mathrm{H} 2)$ postulates that attitude directly affects food safety practices. $\mathrm{H} 2$ is sustained as the SEM demonstrates a positive and significant relationship between the two variables $(\beta 1=0.534, p<0.05)$. There is an insignificant relationship between food safety knowledge and attitude in this study ( $\beta 1$ $=0.005, \mathrm{p}>0.05)$ thus $\mathrm{H} 3$ is rejected.

Table 6 Estimates of hypothesis paths food safety knowledge, attitude and practice

\begin{tabular}{|c|c|c|c|c|}
\hline Hypothesis & Paths & Estimate & $\begin{array}{c}\text { Composite } \\
\text { Reliability (C.R.) }\end{array}$ & P value \\
\hline H1 & Knowledge $\rightarrow$ Practice & -0.284 & -0.765 & 0.444 \\
\hline H2 & Attitude $\rightarrow$ Practice & 0.534 & 19.47 & 0.000 \\
\hline H3 & Knowledge $<-->$ Attitude & 0.005 & 0.837 & 0.402 \\
\hline
\end{tabular}

\section{Discussion}

This is the first study to report on thermometer usage among consumers in Malaysia. The findings support Rhodes and Kuchler [32] who reported similar results i.e. 14\% of at-home meal preparers use a food thermometer during a typical week. The main reason given by the respondents in this study was that they could rely on visual appearance to check if food is thoroughly cooked. This is in line with WHO [33] recommendations to check that meat and fish are thoroughly cooked by making sure that there is no pink meat left, juices should run clear when the thickest part of the meat is 
pierced and fish should be opaque and flakes easily. However, a meat thermometer is used in modern kitchen to measure the internal temperature of cooked food [33]. Other main reasons given were: troublesome to use, don't know how to use and it could be a source of contamination. The barriers to thermometer usage in this study echoes Feng and Bruhn [34] who categorised the barriers into 'belief that a thermometer is not necessary' and 'difficulty of selecting and using a thermometer'. Elsahat, Woodside, \& McKinley [35] identified cooking habits and the influence of society and media as barriers to meat thermometer usage. Other previous studies in developing countries found up to 94\% ( $n=1393)$ consumers in Mainland China [36] and 93\% $(n=1172)$ Lebanese [37] did not use thermometer to check food is cooked. Nik Husain et al. [16] conducted a food safety training intervention study among two groups of food handlers in Malaysia and reported no changes in knowledge on temperature control even after a series of training. One of the main constraints to thermometer usage was their unavailability or lack of thermometers for food handlers [38].

Apart from $\mathrm{K} 4$ and $\mathrm{A} 2$ as discussed below, the empirical results in this study revealed that respondents have good level of food safety knowledge, positive attitude and self-reported practices in safe food handling. This agrees with Odeyemi et al. [9] who reported Malaysian consumers exhibit high food safety knowledge and demonstrate positive food safety attitude and practices. Most respondents in this study reported washing raw chicken before cooking. This is similar to Habib et al. [39] where almost all respondents in Iraq and Egypt shared the practice of washing chicken in water before cooking. Some of the reported reasons for washing chicken before cooking were due to 'food preparation practices taught at home' and 'to remove slime or to mask unwanted smell from raw chicken' [39]. Food safety and public health organisations recommend not washing raw meat and poultry before preparation to reduce risk of foodborne illness due to cross contamination [40-42]. Washing raw poultry and meat could result in contamination of hands, sinks and counter-top surfaces [43].

The respondents in this study generally disagree with the etiquette of sneezing or coughing into the crook of the elbow if one does not have a tissue close by [44, 45]. In Berry and Fournier [46] and Wolff [47], the authors observed that most people coughed directly into their hands and did not immediately clean them. Sneezing and coughing can emit droplets of fluid and potentially infectious microorganisms and travel up to $7-8$ meters $[48,49]$.

Figure 1 and Table 6 indicates that food safety knowledge does not translate into safe food handling practices. Baser et al. [18], Soon [20] and Ko [50] also reported food safety and food allergen knowledge has a negative relationship with food safety practices. This could potentially be characterised by the optimistic bias (OB) phenomenon where consumers felt protected against food safety risks or 'it won't happen to me' [51] or 'he is worse than I am' [52] perceptions. Meanwhile, food safety attitude was identified as an important factor in influencing food safety practices. A 
241 positive attitude indicates the level of motivation and care required to handle food safely. Lim et al.

242 [12] and Ruby et al. [14] similarly reported positive and significant relationship between food safety

243 attitudes and practices among consumers in East Malaysia. Attitude represents beliefs and can serve

244 as a crucial mediator between knowledge and practices [20]. An insignificant relationship between

245 food safety knowledge and attitude reflect that both variables independently influenced practices. Tan

246 et al. [6] found weak correlations between knowledge and hand hygiene attitudes among food

247 handlers in Malaysia while Soon [20] reported similar results among consumers. The current SEM

248 model of food safety knowledge, attitude and practices (KAP) could be combined with the Theory of

249 Planned Behaviour to understand how attitude, subjective norms and perceived behavioural control

250 affect safe food handling practices. Specific KAP models on thermometer usage and handling of raw

251 poultry and meat are worth studying in future studies.

252

253

254

255

\section{Limitations}

This study is based on self-reported practices by a small number of respondents, hence could not be generalised to the whole population. A high percentage of the responses were made by those with tertiary education and this group of respondents are more likely to be aware of food safety issues and are motivated to carry out safe food handling practices. Correct thermometer usage is one of the main factors to consider in ensuring safe food. Although more than $50 \%$ of the respondents who don't use a thermometer reported that they relied on visual cues, there is also the possibility of not owning a thermometer or popularity in using a thermometer in households that should be considered.

\section{Conclusion}

263

The respondents in this study demonstrate good level of food safety knowledge and positive attitudes and self-reported practices. This is also the first study to report new empirical findings on thermometer usage among consumers in Malaysia. Respondents prefer to use visual cues to determine if food is cooked thoroughly while another main barrier was attributed to difficulty in using the device. Another key finding was almost all respondents would wash raw chicken prior to cooking. This could potentially increase risk of foodborne illnesses due to cross contamination. Respondents were also not likely to cough or sneeze into their elbows if tissue is unavailable, raising risk of cross contamination. The structural equation modelling showed a good fit on food safety knowledge, attitude and practices. Within SEM, although respondents are generally knowledgeable about food safety, this did not translate directly into food safety practices. However, attitude has been identified as a significant factor in influencing food safety practices. An insignificant relationship between knowledge and attitude suggests that the attributes affect food safety practices independently. Safe food handling practices at home play a critical role in protecting individuals and households, contributes to an overall improved social and quality of life and reduce burden on national health care. 
The authors are grateful for the open access support from UCLAN Research Centre for Global

Development (C4Globe).

\section{References}

1. World Health Organization. WHO estimates of the global burden of foodborne diseases. Foodborne diseases burden epidemiology reference group 2007-2015. 2015. https://www.who.int/publications-detail/who-estimates-of-the-global-burden-of-foodbornediseases

2. Saad M, See TP, Adil MAM. Hygiene practices of food handlers at Malaysian government institutions training centers. Procedia - Social and Behavioral Sciences. 2013;85:118-127.

3. Abdullah Sani N, Siow ON. Knowledge, attitudes and practices of food handlers on food safety in food service operations at the Universiti Kebangsaan Malaysia. Food Control, 2014;37:210-217.

4. Abdullahi A, Hassan A, Kadarman N, Saleh A, Baraya YS, Lua PL. (2016). Food safety knowledge, attitude and practice toward compliance with abattoir laws among the abattoir workers in Malaysia. International Journal of General Medicine. 2016;9:79-87.

5. Ismail FH, Chik CT, Muhammad R, Mat Yusoff N. Food safety knowledge and personal hygiene practices amongst mobile food handlers in Shah Alam, Selangor. Procedia - Social and Behavioral Sciences. 2016; 222:290-298.

6. Tan SL, Abu Bakar F, Abdul Karim M, Lee HY, Mahyudin NA. Hand hygiene knowledge, attitudes and practices among food handlers at primary schools in Hulu Langat district, Selangor (Malaysia). Food Control. 2013;34:428-435.

7. Woh PY, Thong, KL, Behnke, JM, Lewis, JW, Mohd Zain, SN. Evaluation of basic knowledge on food safety and food handling practices amongst migrant food handlers in Peninsular Malaysia. Food Control. 2016;70:64-73.

8. Abdul-Mutalib NA, Abdul Rashid, MF, Mustafa S, Amin Nordin S, Hamat RA, Osman M. Knowledge, attitude and practices regarding food hygiene and sanitation of food handlers in Kuala Pilah, Malaysia. Food Control. 2012;27(2):289-293.

9. Odeyemi OA, Abdullah Sani N, Obadina AO, Saba CKS, Bamidele FA, Abughoush M, Asghar A, Dongmo FFD, Macer D, Aberoumand A. (2019). Food safety knowledge, attitudes and practices among consumers in developing countries: An international survey. Food Research International. 2019;116:1386-1390.

10. Redmond EC, Griffith CJ. Consumer food handling in the home: A review of food safety studies. Journal of Food Protection. 2003;66:130-161.

11. Soon JM, Singh H, Baines R. Foodborne diseases in Malaysia: A review. Food Control. 2011;22(6):823-830.

12. Lim TP, Chye FY, Sulaiman MR, Suki NM, Lee JS. A structural modeling on food safety knowledge, attitude and behaviour among Bum Bum Island community of Semporna, Sabah. Food Control. 2016;60:241-246.

13. Ruby GE, Abidin UFUZ, Lihan S, Jambari NN, Radu S. A cross sectional study on food safety knowledge among adult consumers. Food Control. 2019;99:98-105. 
14. Ruby GE, Abidin UFUZ, Lihan S, Jambari NN, Radu S. Predicting intention on safe food handling among adult consumers: A cross sectional study in Sibu district, Malaysia. Food Control 2019; 106:106696.

15. New CY, Thung TY, Premarathne JMKJK, Russly AR, Abdulkarim SM, Son R. Microwave oven safety: A food safety consumer survey in Malaysia. Food Control. 2017;80:420-427.

16. Nik Husain NR, Wan Muda WM, Noor Jamil NI, Nik Hanafi NN, Abdul Rahman R. (2016). Effect of food safety training on food handlers' knowledge and practices. A randomized controlled trial. British Food Journal. 2016;118(4): 795-808.

17. Abdul-Mutalib NA, Syafinaz AN, Sakai K, Shirai Y. An overview of foodborne illness and food safety in Malaysia. International Food Research Journal. 2015;22(3):896-901.

18. Baser F, Ture H, Abubakirova A, Sanlier N, Cil, B. Structural modelling of the relationship among food safety knowledge, attitude and behaviour of hotel staff in Turkey. Food Control. 2017;73(B):438-444.

19. Chen M-F. Modeling an extended theory of planned behavior model to predict intention to take precautions to avoid consuming food with additives. Food Quality and Preference. 2017;58:24-33.

20. Soon JM. Structural modelling of food allergen knowledge, attitude and practices among consumers in Malaysia. Food Research International. 2018;111:674-681.

21. Soon JM. Food allergen knowledge, attitude and practices among UK consumers: A structural modelling approach. Food Research International. 2019;120:375-381.

22. Murray R, Glas-Kaastra S, Gardhouse C, Marshall B, Ciampa N, Franklin K, Hurst M, Thomas MK, Nesbitt A. Canadian consumer food safety practices and knowledge: Foodbook study. Journal of Food Protection. 2017;80(1):1711-1718.

23. World Health Organization. Five keys to safer food manual. World Health Organization. 2006. http://apps.who.int/iris/bitstream/handle/10665/43546/9789241594639 eng.pdf;jsessionid=A129 2EBDA0A021C6C60962B812B7D384? sequence $=1$

24. McLeod S. Questionnaires. Simply psychology. 2014. https://www.simplypsychology.org/questionnaires.html

25. Hair JF, Black B, Babin B, Anderson RE, Tatham RI. Multivariate analysis: A global perspective. 2010. New Jersey:Person Education Inc, Upper Saddle River.

26. Hair JR, Anderson RE, Tatham RL, Black, WC. Multivariate data analysis. $5^{\text {th }}$ Ed. 1998. New Jersey:Prentice-Hall.

27. MacCallum RC, Browne MW, Sugawara HM. Power analysis and determination of sample size for covariance structure modelling. Psychological Methods. 1996;1(2):130-149.

28. Hu L-T, Bentler PM. Cutoff criteria for fit indexes in covariance structure analysis: Conventional criteria versus new alternatives. Structural Equation Modeling: A Multidisciplinary Journal. 1999;6(1):1-55.

29. Kline RB. Principles and practice of structural equation modelling. 1998. Guilford Press, New York.

30. Hooper D, Coughlan J, Mullen M. Structural equation modelling: Guidelines for determining model fit. Electronic Journal of Business Research Methods. 2008;6(1):53-60. 
31. Bentler PM, Bonnet DC. Significance tests and goodness of fit in the analysis of covariance structures. Psychological Bulletin. 1980;88(3):588-606.

32. Rhodes MT, Kuchler F. The influence of time use, risk factors and occupation on meal preparers' use of food thermometers. Food Protection Trends. 2020;40(1);16-28.

33. World Health Organization. Food safety: what you should know. 2015. http://origin.searo.who.int/entity/world health day/2015/whd-what-you-shouldknow/en/

34. Feng $\mathrm{Y}$, Bruhn $\mathrm{CM}$. Motivators and barriers to cooking and refrigerator thermometer use among consumers and food workers: A review. Journal of Food Protection. 2019;82(1):128-150.

35. Elsahat S, Woodside JV, McKinley MC. Meat thermometer usage amongst European and North American consumers: A scoping review. Food Control. 2019;106:106692.

36. Gong SL, Yang YS, Shen H, Wang XY, Guo HP, Bai L. Meat handling practices in households of Mainland China, Food Control. 2010;22(5):749-755.

37. Hassan HF, Dimassi H. Food safety and handling knowledge and practices of Lebanese university students. Food Control. 2014;40:127-133.

38. Webb M, Morancie A. Food safety knowledge of foodservice workers at a university campus by education level, experience, and food safety training. Food Control. 2015;50:259-264.

39. Habib I, Harb A, Hansson I, Vagsholm I, Osama W, Adnan S, Anwar M, Agamy N, Boqvist S. Challenges and opportunities towards the development of risk assessment at the consumer phase in developing countries - The case of Campylobacter cross-contamination during handling of raw chicken in two Middle Eastern countries. Pathogens. 2020;9(62)

40. Centers for Disease Control and Prevention. Foods that can cause food poisoning. 2019. https://www.cdc.gov/foodsafety/foods-linked-illness.html

41. Government of Canada. Does washing food promote food safety? 2016. https://healthycanadians.gc.ca/recall-alert-rappel-avis/hc-sc/2016/57088a-eng.php

42. National Health Service. Why you should never wash raw chicken. 2017. https://www.nhs.uk/live-well/eat-well/never-wash-raw-chicken/

43. Mazengia E, Fisk $C$, Liao $G$, Huang $H$, Meschke J. Direct observational study of the risk of crosscontamination during raw poultry handling: Practices in private homes. Food Protection Trends. 2015;35(1):8-23.

44. Centers for Disease Control and Prevention. Coughing and sneezing. 2016. https://www.cdc.gov/healthywater/hygiene/etiquette/coughing sneezing.html

45. European Centre for Disease Prevention and Control. How can you protect yourself and others from infection. 2020. https://www.ecdc.europa.eu/sites/default/files/documents/covid19leaflet-public-travellers-EC-en.pdf

46. Berry TD, Fournier AK. Examining university students' sneezing and coughing etiquette. American Journal of Infection Control. 2014;42(12):1317-1318.

47. Wolff R. No cover-up here: A descriptive study of observations of coughing on hands and the lack of proper respiratory hygiene behaviors or cough etiquette. SSRN. 2020;3565981. 
48. Bourouiba L. Images in clinical medicine: a sneeze. New England Journal of Medicine. 2016;375(8):e15.

49. Bourouiba L. Turbulent gas clouds and respiratory pathogen emissions. JAMA Insights. 2020;doi: 10.1001/jama.2020.4756

50. Ko W-H. The relationship among food safety knowledge, attitudes and self-reported HACCP practices in restaurant employees. Food Control. 2013;29:192-197.

51. Weinstein ND. Why it won't happen to me - perceptions of risk-factors and susceptibility. Health Psychology. 1984;3(5):431-457.

52. Da Cunha DT, Stedefeldt E, de Rosso VV. He is worse than I am: The positive outlook of food handlers about foodborne disease. Food Quality and Preference. 2014;35:95-97.

\section{Supporting information}

SI Questionnaire. Food safety knowledge, attitude and practices among consumers in Malaysia 